\title{
The Public Savings' Relation With Borrowing Requirement and Financial Balances After Global Crisis in Turkey
}

\author{
Niyazi ÖZKER \\ Bandirma Onyedi Eylul University, Bandirma, Turkey
}

\begin{abstract}
In this study, we aim to determine public savings' structural location in the analysis of effect levels that are related to public borrowing requirement to cope with the deviation of financial balances, especially after 2009 global crisis in Turkey. Public savings as a financial option take up an important place in the scope of expressed government budget balances related to public borrowing requirements which are increasingly located together with budget deficits. This fact especially is pertaining to investments and capital's transfers that are subject to the public decision making process towards economic growth in the future in developing countries like Turkey. Therefore, increasing public savings' limits appear on these countries as an inevitable financial phenomenon concerning the desired investments. Turkey, as a developing country, has faced two financial phenomenons that increase borrowing requirement terms that lead to intend financial balances that have generally deviated after 2009 financial crisis. Firstly, it's increasing foreign debt burden and the public savings' levels that have not been enough to cover all the proportion of foreign debt payments since 2009. Secondly, the effect level of global crisis on the exchange rates directly causes the deviation of national currency values as a meaningful important negative impact on budget balances that are aimed at together with the macroeconomic financial balances.
\end{abstract}

Keywords: financial crisis, foreign debt burden, national investments, public borrowing requirement, public savings

\section{Introduction}

In the several years prior to 2009, Turkey's financial location was engaged in heavy borrowing from foreign private investors which aimed at domestic spending to outpace incomes that come to domestic economic crisis. As a developing country Turkey's financial savings balances aimed to equal to the difference between domestic savings and domestic investment spending in the concerned years, which means to cope with 2009 global financial crisis being taken lessons from previous 2001 economic crisis. In this context, especially the lack of public savings has affected increasingly the differences of value between saving-investment and capital transfers such as financial components in Turkey after 2009 (Kalkınma, 2015). In Turkey, there are important financial differences among the central government budget that includes public savings' limits with the difference of investments-public savings as to how financial vulnerabilities evaluated, which is considered as macroeconomics' locomotive engine power. So, it appears that Turkey has begun to act towards increasingly public savings that aimed at the financial structure in the scope of the public financial applications and effective

Niyazi ÖZKER, Dr., Associate prof., Public Finance Department, Faculty of Economic and Business Administration, Bandirma Onyedi Eylul University, Bandirma, Turkey.

Correspondence concerning this article should be addressed to Niyazi ÖZKER, Public Finance Department, Faculty of Economic and Business Administration, Bandirma Onyedi Eylul University, Canakkale Yolu, 2.km., Bandirma 10200, Turkey. 
national investments since the global crisis of 2009. The financial objective there is that Turkey's saving balance keeps to be equal to the difference between domestic savings and domestic investment spendings especially after the global financial crisis of 2009 (Rodrick, 2009). It is not possible to say that Turkey's saving-investment in the central government budget was not healthy from a growing and stable perspective in the period of leading up to the global financial crisis of 2009, even though central budget balances have been keeping as the positive effect level in the increasing values that are related to gradually incentive investments from day to day. This fact also means how Turkey became dependent on foreign borrowing, which aimed at the structural growth that causes the more borrowing requirement in the adjusting process of access to foreign capital. In this context the public sector borrowing requirement, as a proportion of GDP, shed light on having an important location in the public budget that expresses the other financial items, related directly with public savings, capital transfer, and financial case-banking as percent of borrowing. The public sector borrowing requirement may also mean the government's budget deficits in terms of financial items (deficits) that are financed by borrowing funds from the public, usually by the means of government's finance politics. In the borrowing requirement, Turkey has faced some financial matters among financial balance's measures especially related to government's effect finance politics, and this fact resulted in the declined investment spendings as a share of GDP that are connected with the global crisis of 2009 (Borio \& Disyatat, 2011). After the global crisis of 2009, public borrowing requirement has taken a more important position for analyzing public save balances together with investment and foreign debt levels as an important financial indication, which especially tends to increase public savings (Rodrick, 2009). Therefore, it means that public savings in modern transparent public liabilities inevitably have been considered aiming to direct public savings to investments with budget balances since 2009.

\section{Financial Balances and Investments' Location in the Global Crisis’s Process}

Since 2009 including the process of global crisis, and up to the present years financial balances have been appeared meaningful alterations, which mean different financial formations related to borrowing requirement (Blejer \& Cheasty, 2012). Namely, investments' location with its relations with borrowing requirement has been affected via changeable different public savings' limits in the ground of invariable capital. Moreover, this fact expresses national savings including public savings is more than needed to support domestic capital expenditures to keep increasingly national investments in that depending on the levels of public savings. Therefore the public savings that are related to public investment including constant capital and stock alterations, as a current transfer item, need to be the financial feedback via wealth taxes together with expropriation revenues in the scope of capital revaluation (Campello, Graham, \& Harvey, 2009).

\section{The Location of Public Savings Related With the Other Macroeconomics Values in Developing Countries}

The main goal for us is which level macroeconomic remedies are being expressed to ensure the desired financial ground that constitutes the financial balance dynamics via public saving levels in the process financial crises. In this context financial balances that take place in financial crisis can be considered two terms related to public savings' locations in the scope of macroeconomics balances especially for developing countries after 2009. Firstly, this financial fact is related to public savings' limits which mean that taxable public revenues are corresponding with household' increasing (or decreasing) savings (Gale, 2014), and household revenues increasing position affects positively the collected tax revenues and also ensures to control the possibility of 
public deficits in crisis. On the other hand, this approach, as in the global financial crisis of 2008-09 and the spreading crisis in Europe, has produced many questions on the agenda of public savings regarding the medium or long-term response to crises in the scope of macroeconomics' balances (Campello, Graham, \& Harvey, 2009). If the public sector typically does not need to adjust public savings' behavior immediately in the face of a crisis, this financial phenomenon can result in the inevitable delayed adjustment, preferable and attainable to exposure to crises that express increasing tax burden on taxpayers dealing with global crisis (Rosen, 2012). This situation comes to mean that global financial crisis connected with public savings politics is remarkably unsuccessful to cope with financial crisis dynamics. The variable effects of public savings that influence the other macroeconomics' structural values are seen in developing countries related to 2013 (Table 1, below).

Table 1

Public Savings and Their Structural Effects in Some Developing Countries

\begin{tabular}{llllll}
\hline The troubled five & Inflation & Current account deficit & Savings & Public Debt & Unemployment \\
\hline Brazil & 6.3 & 3.4 & 15.8 & 68.3 & 5.8 \\
Indonesia & 7.3 & 3.4 & 31.2 & 26.2 & 5.9 \\
South Africa & 5.9 & 6.1 & 13.2 & 43 & 26 \\
India & 10.9 & 4.4 & 30.6 & 67.2 & 9.8 \\
Turkey & 7.5 & 7.5 & 12.6 & 36 & 4.1 \\
The Control Group & & & & & 3.2 \\
China & 2.7 & -2.5 & 51.4 & 22.9 & 5.7 \\
Korea & 1.4 & -4.9 & 31.4 & 35.7 & 14.1 \\
Russia & 6.7 & -2.9 & 28.3 & & \\
\hline
\end{tabular}

Source: http://www.tepav.org.tr/en/blog/s/4513 (16.07.2016).

Table 1 shows public savings related to some macroeconomics indicators in some developing countries that include Turkey in 2013. It is apparent that if national savings levels including public savings values decrease public debt levels will take into remarkably increasing period. And also, it is seen that current account deficits were connected with national savings limits including public saving values, public debts with national savings, as a proportion of percent of GDP, manipulated directly current account deficits levels even if there is possible middle level inflation in the same period in 2013. As seen on table 1, unemployment and inflation rates are not only fairly affected by public savings in 2013, but also public saving levels express the level of economic developing in these countries. However, debt ratios related to private investments, as a proportion of GDP, can be considered as an important sign of national savings on the level of economic development process due to meaningful national saving levels. And also, after the global crises, gross national savings' location that is related to debt ratios especially non-financial private sector debts, as a proportion of GDP, is seen on Figure 1 below from different viewing points.

Figure 1 expresses national savings that include public savings in some developing countries from a view of different opinions relating to developing countries including Turkey. In this context, it is apparent that national savings including public savings especially increase while GDP's level increases in the considered period of 2013 as an example. Surely, it can be said the national investments increased especially including public investments while equivalent of increased GDP in the same period of 2013 means that sustainability economic growth in deal with cases. This fact comes to mean that each country priority for national saving policy objectives is different because each has a different national debt ratio, and financial politics' suggestions 
provide flexibility to implement saving rules in a manner consistent with the policy objectives of the overall tax system and the international legal obligations of the countries concerned for each country (Hays, 2003).

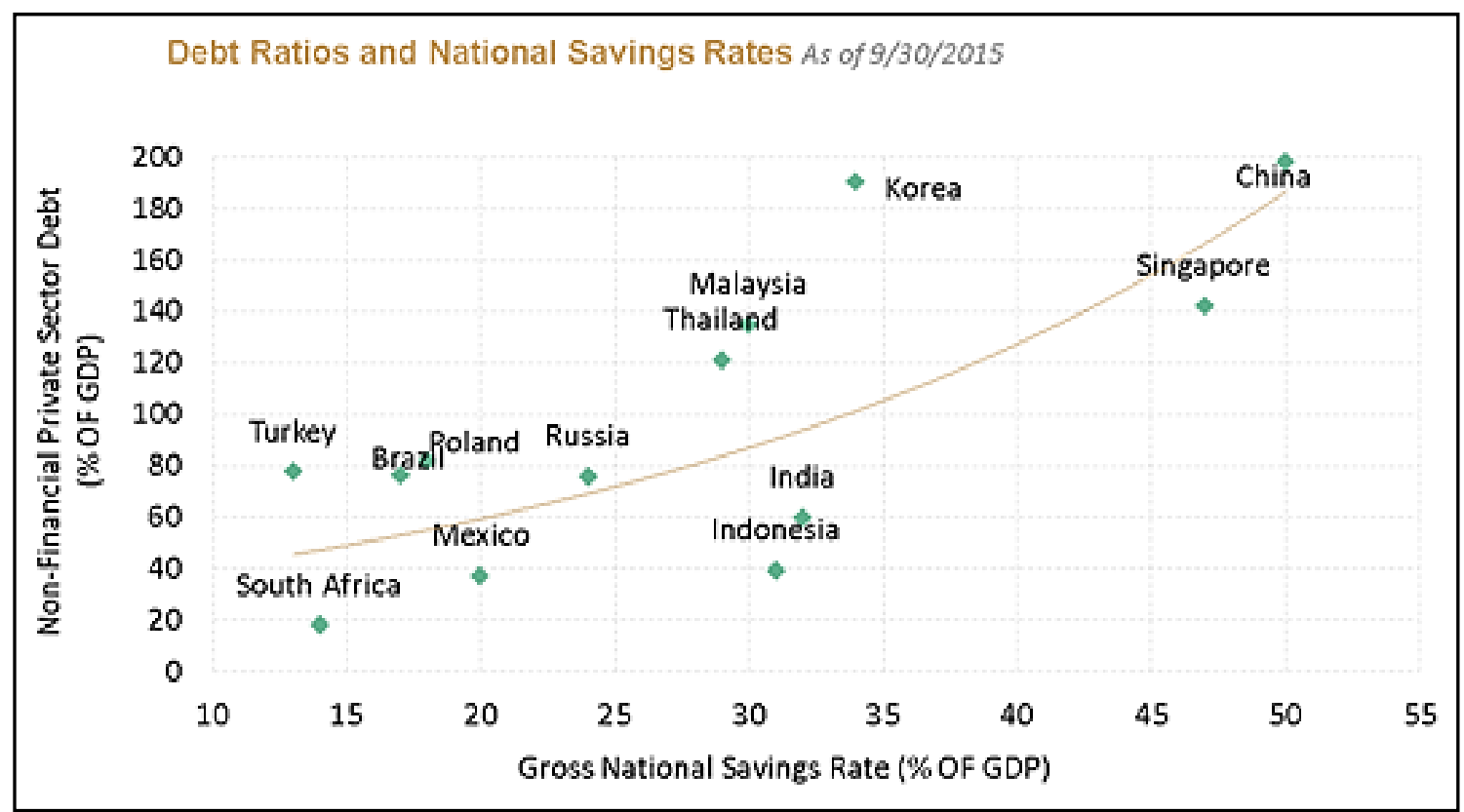

Figure 1. National savings location in 2013 after the financial global crisis in 2009. Source: https://brandywineglobal.com/aroundthecurve/index.cfm?page=article\&content= 984700710 (28.07.2016).

\section{The Borrowing Requirement Relation of Public Savings and National Investments' Location After Global Crisis}

The important relation of the level of public savings appears on the ground of borrowing requirement that also steers national investments' level especially in the process of financial crisis or after this process of financial investment phenemeneon after global financial crisis (Shin, 2009). Debt levels, especially in EU countries, need borrowing requirement in touch with public saving of each country towards investment after global financial crisis (Shin, 2009). According to the public savings of each country, in the euro area as a whole, the most important motive for savings is the provision for unexpected events which captures the different borrowing levels related to savings motive after the 2009 global financial crisis (Crotty, 2008). Figure 2 below states European debt ratios that mean public borrowing requirement as a proportion of GD.

Figure 2 sheds light on the borrowing requirement as a proportion of GDP related to public saving ratios, which means that saving is a factor to influence the level of investment. If there is an increase in savings, then debt ratios can lend more to firms for finance investment projects. This fact is meaningful as a simple economic model and we can say the level of saving should move in the orbit of debt process equal to the level of investment. In this context, investment in economics is defined as an addition to the capital stock related to debt ratios to GDP (Moghodam \& Canuto, 2010). As seen on Figure 3 below, developed countries in EU have more positive investment signs related to directly national investment due to sufficient public savings that include financial enterprises with financial stock supporting investments.

This phenomenon results in the fact that especially developing countries like Turkey deprive of investment capital stock because of not being sufficient public savings levels. In other words, each country that has the declined debt ratios has also increasing public saving limits which are exposed to bring out increasing national 
investment together with more positive macroeconomics indicators. But, countries in Eurozone have been in the declined macroeconomic process due to their public savings within negative values towards economic growth for a long time which are related to national investments after global financial crisis (European Commission, 2009).

\section{Government Gross Debt as a Percetage of GDP}

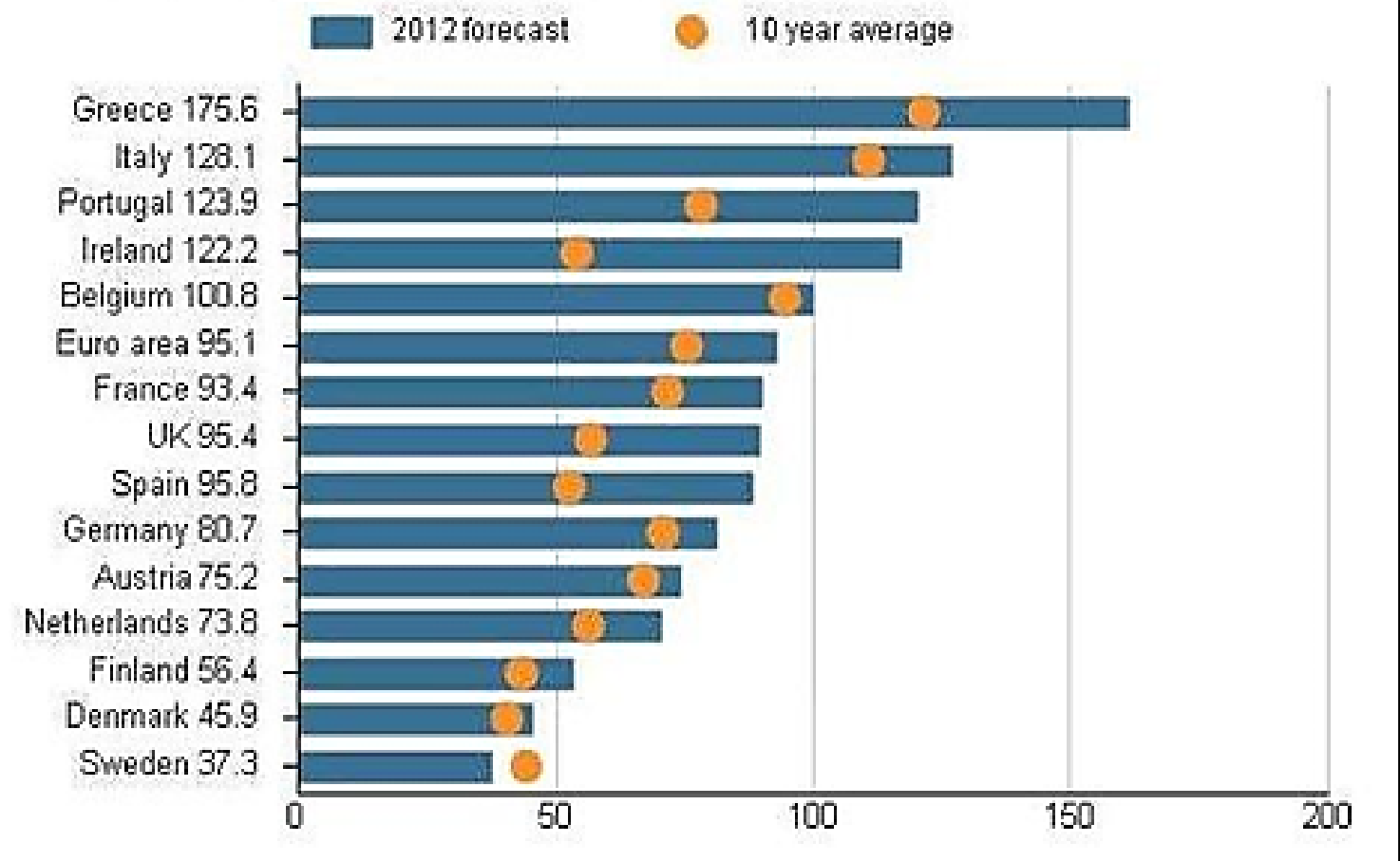

Figure 2. Gross debt ratios related to borrowing requirement to GDP.

Source: http://www.fxstreet.com/analysis/european-crisis/2013/04/19/(21.07.2016).

\section{EUROZONE}

- GDP: $-0.6 \%$ Q०Q (Q4 2012)

- Industrial Production: -1.3\% YoY (Jan 2013)

- Trade Balance: €10.4B (Feb 2013)

- CPI: $1.7 \%$ YoY (Mar 2013)

- PPI: $1.3 \%$ YoY (Feb 2013)

- Unemployment: 12\% (Feb 2013)

- Consumer Confidence: -23.5 (Mar 2013)

- Retail Sales: -1.3\% YoY (Jan 2013)

- ECB Interest rate: $0.75 \%$ (since July 11, 2012)

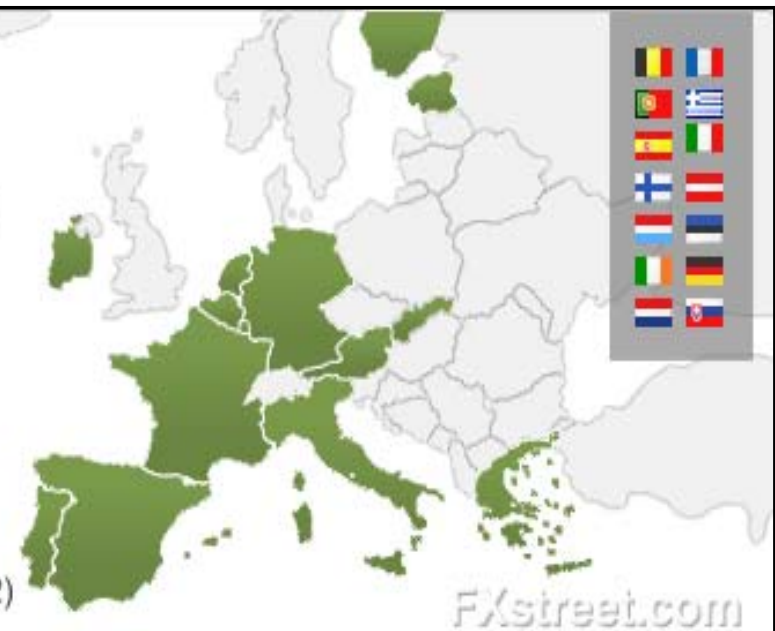

Figure 3. Some macroeconomic signs that are related to public savings levels in Eurozone.

Source: http://www.fxstreet.com/analysis/european-crisis/2013/04/19/(25.07.2016). 


\section{Public Savings Location That Are Related to Borrowings in Turkey After Global Crisis}

After global crisis in 2009, Turkey's macroeconomic balances have been not extremely affected via borrowing requirements that also define national savings including public savings until today. However, it can be said that the credit billfolds of all the financial institutions have been located in more tightly fitting of narrow ground of financial operations in the scope of their own accounts after the same crisis period. In other words, public savings investment balances together with private savings related to private investments have taken a stand in differential reverse level from each other as national saving rations after 2009 in Turkey (BDDK, 2010).

\section{Saving and Investment Balances in Turkey After 2009 Financial Crisis}

Public savings, as a proportion of GDP, have seen pretty wavy appearance since 2007, which includes global crisis process directly in touch with borrowing requirement levels. This financial situation has been also reflected on investment levels with saving-investment difference, which means declination on the aim of public saving levels also directing private investments for same years. However, it is not possible to state Turkey has sufficient public savings that has been aimed since 2007, and also national investment levels have not been efficient from global crisis years to today (BDDK, 2010). Table 2 below points at public savings in touch with investments and borrowing requirement levels as a percent of GDP after 2007, which simultaneously includes years of global financial crisis.

Table 2

Public Savings and Investment-Capital Balances in Turkey After Global Financial Crisis

\begin{tabular}{llllll}
\hline Year & Public savings/GDP* & $\begin{array}{l}\text { Borrowing } \\
\text { Requir./GDP* }\end{array}$ & Investment/GDP* & $\begin{array}{l}\text { Savings-investment } \\
\text { difference/GDP* }\end{array}$ & Fixed capital/GDP \\
\hline 2007 & 2.4 & -0.1 & -3.9 & -1.5 & -3.9 \\
2008 & 1.7 & 0.0 & -4.3 & -2.6 & -4.1 \\
2009 & -0.8 & -0.4 & -4.4 & -5.3 & -4.1 \\
2010 & 1.5 & -0.6 & -4.1 & -2.5 & -4.3 \\
2011 & 3.7 & -0.2 & -4.1 & -0.4 & -4.1 \\
2012 & 2.9 & -0.1 & -4.4 & -1.5 & -4.2 \\
2013 & 3.4 & -0.3 & -4.9 & -1.5 & -5.0 \\
2014 & 3.6 & 0.2 & -4.8 & -1.7 & -5.1 \\
2015 & 3.3 & -0.1 & -4.6 & -1.9 & -4.9 \\
\hline
\end{tabular}

Note. ${ }^{*}(-)$ as financial surplus. Source: Development Ministry.

If public savings increase the borrowing requirement becomes less as mutually financial values after global crisis, and this investment ratio decreas too. The goal is that the current account deficit equals the capital account surplus as a Keynesian approach, that can state as "Investment = Private Savings + Public Saving + Capital Inflows". But, the levels of fixed capital should not be noticed because of the changeable wavy location of public savings after 2007. As seen on Table 2, public savings levels were in the most less location and savings-investment differences were also, as a proportion of GDP, the most high in this same year, but then it has been seen more the whole balanced relation in the later years. The financial location and its structural relation can be explained in two terms related to the considered years. First, the levels of public savings have not been sufficiently increased after 2007 to today and this phenomenon has resulted in the deviation of national investments that should manipulate positive economic growth. Second, public savings have been used 
for budget deficits, but not for national investments including financial incentives. This financial formation has been obstructed to national investments increasing the savings-investment differences as a the undesired fact after 2007 (Ganioğlu \& Yalçın, 2013).

\section{The Location of Saving-Investment Balances in Public Sector Together With Private Sector in Turkey}

\section{After 2007}

As national investments both savings of public and private sector are fairly important with respect to investments, but private sector savings are more meaningful than the other in Turkey as real values after 2007. Especially private sector saving-investment balances have been pretty increasing, while public sector saving-investment values have been decreasing to under zero before global financial crisis in 2001 (Kaya, 2008). But, both of sectors that have financial saving values with saving-investment balances have been seen generally under zero values, and this situation has produced continually the negative financial limits of public saving-investment balances as a proportion of GDP towards presently financial accounts (Ganioğlu \& Yalçın, 2013). Figure 4 below shows the location of saving-investment balances in public sector together with private sector including years of global financial crisis.

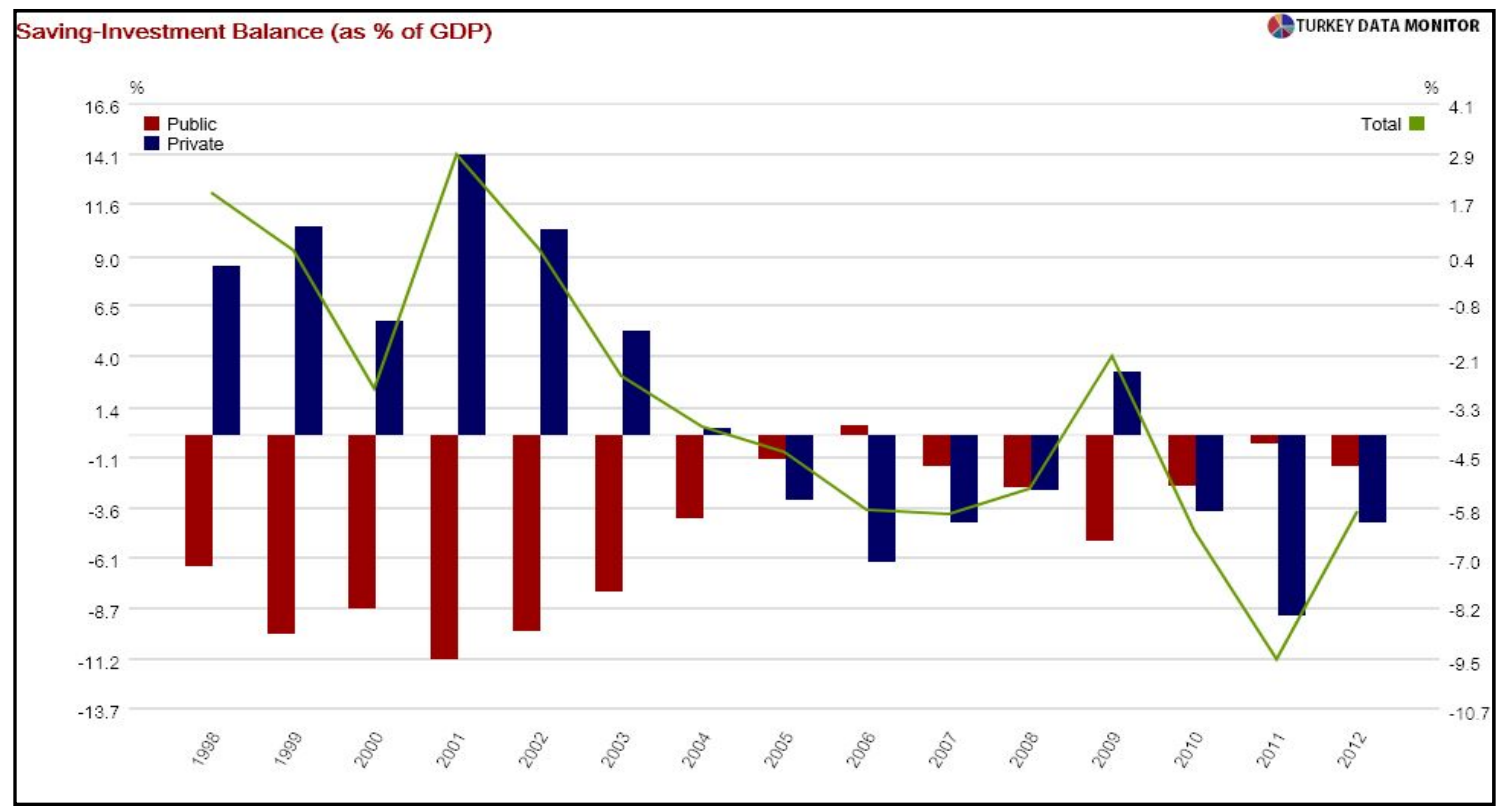

Figure 4. Saving-investment balances in public sector together with private sector.

Source: http://www.hurriyetdailynews.com/turkey-navigating-the-road-to-sustainable-growth.aspx?page,ID=449\&nID $=59095 \&$ NewsCatID $=430$.

As seen on Figure 4, the matter that should be analyzed, the net saving, and investment relations do not indicate a fall over time similar to the corresponding gross saving investment coefficients in Turkey. In other words, from the observed Figure 4, saving-investment correlation is also important for assessing whether investment income causes a capital outflow that permits the incidence of the private investments via public savings to reach to aimed employment levels (Bölükbaşı \& Ertugal, 2013). But, this financial matter is not easy as seen in Turkey due to this difference between the gross and net saving-investment as real relations are more complex between the changes over time in Turkey. The pattern of the savings retention coefficients differs even more sharply between public and private sector, and this situation has been considered to get in the current 
context of comparatively long-term differences in national investment rates directing towards saving-investment balances after years of global crisis in Turkey. Although we regard this as an ingenious demonstration how the observed investment-saving relation might in principle be just a real reflection of the missing growth and production factors variables, we do not find it convincing (Bryson \& Nelson, 2015). The real analysis of the saving variables, just a meaningful power for the growth and investment variables or not, is whether the inclusion of growth depends on the political stabilization, not only public savings (Ganioğlu \& Yalçın, 2013). So, Turkey needed more stabile national savings that include public savings, but as better private saving levels for national investments in especially financial institutions after global crisis.

\section{Conclusion}

The current public savings' limits note that the improvement of budget institutions together with the other financial liabilities that are related to borrowing requirement has been important for Turkey, which avoids the future financial crises similar to the 2009 as a global financial crisis. Public decision making process should be discussed on the policy authority of legislatures often questioning their ability to influence public savings policy. So, this is the tax case not just for public savings, but also usually for budgetary decisions to ensure saving-investments balances in general. In this context, public saving-investment policies should take national tax policies into consideration in order to bring up a meaningful formation towards macro public saving and national investments structure. To be useful in stimulating public savings have to be transparent, and furthermore an important factor that can increase saving levels or enhance the saving usefulness of a tax review which is the structural public extent to the necessary profile needed of saving-investment balances to be a catalyst to the public of the tax system. If developing countries aim to reach the desired public saving together with private savings on the ground of national investments like Turkey, they must improve all financial systems firstly to ensure taxable ability of their countries within meaningful saving-investments balances especially coping with global financial crises.

As for Turkey public saving-investments balances that are related to public borrowing requirements have not sufficiently appeared to buildup as saving values in 2007 to today financial balances. Especially, it is not possible to talk about national investments' real increasing after global crisis respecting the national saving limits, and whole national values, have not been in the desired optimal financial balance location. The improved national saving policies should be about the idea of composite tax legislation effects in the same process on the political and the technical to support national savings especially with private savings in Turkey in balance with public borrowing requirements. In other words, both public savings and private savings were supported from the taxable values ground in order to reach the desired budget financial accumulations after years of global crisis should nourish public borrowing requirement. But, in Turkey it requires not to forget that this phenomenon is often the more political issues that affect the current financial arrangements as the technical probably changes especially turnning toward private saving-investment balances. In this situation, to be increased public savings with the other national savings has been more political issues than financial subject, and the government budget's financial location needed structurally financial reforms to ensure desired national saving-investment after global crisis in Turkey, not only financial incentives.

\section{References}

kaya, H. (2008). Savings-investments association in Turkey. Marmara University Department of Economics Working Paper (No. 
200803, June 2008).

BDDK (2010). From crisis to financial stability (Turkey experience). Banking Regulation and Supervision Agency (BDDK) Working Paper, September 2010.

Blejer, M., \& Cheasty, A. (1991). The measurement of fiscal deficits: Analytical and methodological issues. Journal of Economic Literature, 29(2), 1644-1678.

Bryson, H. J., \& Nelson, E. (2015). Turkey: Stronger savings \& investment needed. Retrieved (August 6, 2016) from https:/www08.wellsfargomedia.com/assets/pdf/commercial/insights/economics/international-reports/turkey-outlook-201512 10.pdfs

Bolukbasi, H. T., \& Ertugal, E. (2013). Europeanisation of employment policy in Turkey: Tracing domestic change through institutions, ideas and interests. South European Society and Politics, 18(2), 237-257.

Borio, C., \& Disyatat, P. (2011). Global imbalances and the financial crisis: Link or no link? (May 2011). BIS Working Papers (No. 346). Bank for International Settlements, Basel.

Campello, M., Graham, J., \& Harvey, C. R. (2009). The real effects of financial constraints: Evidence from a financial crisis. NBER Working Paper Series Working Paper, 15552.

Crotty, J. (2008). Structural causes of the global financial crisis: A critical assessment of the "new financial architecture". Cambridge J Econ (2009), 33(4), 563-580.

European Commission. (2009). Economic crisis in Europe: Causes, consequences and responses. European Economy-7 2009 Economy Economic \& Financial Affairs.

Gale, W. G. (2014). Effects of income tax changes on economic growth. Economic Studies at Brookings, September 2014.

Ganioğlu, \& Yalçın. (2013). Domestic savings-investment gap and growth: A cross-country panel study. Central Bank Republic of Turkey Working Paper, 13/46, December 2013.

Hays, J. C. (2003). Globalization and capital taxation in consensus and majoritarian democracies. World Politics (September 2003), 56, 79-113

Kalkınma, B. (2015). Ekonomik ve sosyal göstergeler (July 2015). Ankara: Kalkınma Bakanlığ1.

Moghadam, R., \& Canuto, O. (2010). Preserving debt sustainability in low-income countries in the wake of the global crisis. International Monetary Fund \& World Bank, April 2010.

Rodrick, J. (2009). The Turkish economy after the crisis. Turkish Economic Association Working Paper 2009-9. Ankara: Turkish Economic Association, 2009.

Rosen, H. R. (2012). Growth, distrubition, and tax reform: Thoughts on the romney proposal. Griswold Center for Economy Policy Studies Working Paper, 228.

Shin, H. S. (2009). Reflections on northern rock: The bank run that heralded the global financial crisis. Journal of Economic Perspectives, 23(1), 101-119, Winter 2009. 